\title{
Daughters are Taking Over Family Businesses
}

\section{Chris Farrell}

\author{
KEYWORDS: Entrepreneurship, Family Business,
} Women.

This article is part of America's Entrepreneurs (https://www.nextavenue.org/special-report/americas-en trepreneurs-a-special-report-from-richard-m-schulzefamily-foundation/) , a Next Avenue initiative made possible by the Richard M. Schulze Family Foundation (https://www.schulzefamilyfoundation.org/) and EIX, the Entrepreneur and Innovation Exchange (https://familybusiness.org/)(https://familybusiness.org/) .)

Family-run firms comprise some 90 percent of business enterprises in the U.S. and about two-thirds of employment. So what happens with family businesses matters greatly to the economy and society. That's why it's important to highlight how the demographics of aging are exerting a revolutionary impact on family businesses - for the better.

Some 10,000 boomers daily are turning 65 , on average. Among them are the mostly male founders and leaders offamilybusinesses(https://www.nextavenue.org/familybusiness-succession-successful/). They're increasingly passing on ownership and leadership of the family enterprise to their daughters, even in traditionally maledominated industries.

"I see more and more daughters. It's a big change, especially in the last few years," says Ritch Sorenson, professor in family enterprise at the Opus School of Business at the University of St. Thomas in Minneapolis and a member of the editorial board of Familybusiness.org(https://www.familybusiness.org/) and EIX, the Entrepreneur and Innovation Exchange (https://familybusiness.org//https://familybusiness.org/)

\section{Flannery Construction: Like Father, Like Daughter}

Take Gerry Flannery and his daughter, Jamey, of St. Paul, Minn.
Gerry started Flannery Construction with a half-time carpenter in the late 1970s. These days, the mid-sized general contractor specializes in multifamily residential and commercial office buildings in the Twin Cities metro area, with 45 employees. Five years ago, when he was 65 , Gerry started the process of turning over the company to Jamey.

She became full owner and chief executive officer when the sale went through in June 2015.

"I had faith in her ability," says Gerry. "I'm pragmatic, and it was time to do something. We did."

Jamey, now 41, had joined the company 15 years ago following college and several marketing jobs. Her work at the business over time included marketing, starting the warranty and services department, project management and sales.

Jamey's sister, who writes computer code, had no interest in the business and supported the sale.

Under Jamey Flannery's leadership, revenues have been up some 40 to 50 percent. Her dad doesn't work as many hours as before, but still puts in 30 to 35 hours a week, focusing on business development and budgeting.

Although father and daughter talk several times a day, Gerry quips that one reason the leadership transition has been successful is that he's learned "to zip it." Their relationship has evolved from parent and child to professional, and respectful, business partners.

"I am an employee at will," Gerry says.

"At his will," Jamey quickly quips."

Women entrepreneurs like Jamey Flannery are gaining power and influence. Women-owned family businesses have increased by 58 percent since 2007 and nearly 25 percent of family businesses are led by a woman CEO

Copyright ( 2019 The Authors. Entrepreneur \& Innovation Exchange is published at EIX.org. This is an open access article under the terms of the Creative Commons Attribution-NoDerivs License, which permits use and distribution in any medium, provided the original work is properly cited and 
or president. Almost 60 percent of family businesses have women in top management positions.

"It's really about breaking down the rigidity of gender norms," says Jill Hoffman, executive director of the Columbus-based Conway Center for Family Business, a resource to the more than 6,000 family-owned businesses in Central Ohio. "Not so much nepotism anymore but about cultivating the next generation of leaders - and many of them are women."

\section{Kathy Gatterdam: Fifth-Generation CEO}

Like Kathy Gatterdam, 54. Her dad, John (Larry) Niemeyer, was the fourth-generation owner of Columbus Coal \& Lime, founded by German immigrant Carl Niemeyer in 1888 . The company sells masonry materials, concrete restoration chemicals and rebar fabrication to the residential and commercial construction industries. After Gatterdam launched her legal career, she joined the company in 1995, at 32 , when her father asked for her help.

He kept giving her more responsibility and began taking longer vacations, leaving his daughter in charge. "When I came in, I wasn't given guidance unless I asked," she says. "I wish I had asked more."

Larry Niemeyer died at 69 in 2009 and, following a family meeting, Kathy became the company's fifthgeneration CEO.

The generational passing of the torch could accelerate in coming years, assuming the economy remains healthy, as growing numbers of family business owners retire. While the CEOs may change, the family values behind the enterprises likely won't.

"I find that family values are embedded in the business," says Sorensen. The Flannerys agree with that assessment. There were three common phrases in their family: Do what you say you're going to do when you say you're going to do it; contribute to the family, community and the greater good and, if it's funny, say it.

"Those end up being the core values of the company," says Jamey. "That's what Gerry built it on and what I want to sustainably grow."

Odds are, it won't be long before the phrase "maledominated industry" will fade into history. The only question retiring family business owners will need to answer: Who is the best person to manage the company?

\section{Learn More:}

Advice, Best Practices and Inspiration for Women Entrepreneurs(https://familybusiness.org/women)

Additional search terms: women, feminism, leadership, leading a family firm, taking over from a guy, female founders, women business owners, glass ceiling, sexual discrimination, bias, opportunity 